\title{
Quality Matters for Turkish Higher Education
}

\author{
Colin Latchem \\ Open and Distance Learning Consultant, Australia \\ clatchem@iinet.net.au
}

\begin{abstract}
The paper examines global developments in quality assurance (QA) in higher education and the imperatives that are driving these. It argues that universities need to respond to the growing calls for accountability, national and international competition in higher education, availability of quality open courseware and expectations that graduates should demonstrate the generic attributes required for the twenty-first century. The paper discusses how quality should be monitored and measured. It posits that quality can never be taken for granted, but has to be continually worked for. It also suggests that innovators in on- and off-campus pedagogy and e-learning need to evidence that they can achieve better outcomes than the more time-honoured approaches. At a time when Turkish universities are becoming increasingly engaged in QA and there is an ongoing debate on the governance issue, the paper is designed to raise issues for further consideration by managers and academics.
\end{abstract}

Keywords: Quality assurance in higher education; innovators in on- and off campus pedagogy; Turkey

\section{Introduction}

The rapid expansion of higher education across the globe has resulted in diverse range of public and private, cross-border and distance education providers. This proliferation of higher education institutions, together with increased staff and student mobility and a growing number of regional and international integration processes, generates the need for comparative evaluation, the means of identifying transportable and transnational methods, systems and good practice, and sound quality assurance (QA) and accreditation systems. Governments in many countries also expect their higher education systems to be more accessible, more affordable and more accountable for their outcomes with the resources they are granted.

Fisher et al (2000) observe that there are five performance models for assuring quality and providing incentives for universities to perform well:

- Assessment and review by accreditation or certification bodies which enable institutions, programmes or courses of study to be recognised or certified as meeting certain specified standards. 
- Quality audits by government ministry-established agencies which involve institutional selfreviews which are then verified by external review teams which make recommendations for improvement and monitor progress.

- Performance funding and performance budgeting schemes relating to governmental priorities.

- Performance reporting and ranking by governments, UNESCO, OECD, the World Bank, Shanghai Jiao Tong University, Times Higher Education and Quacquarelli Symonds, Informatics Institute of Middle East Technical University, and others.

- National or sector-wide student surveys, as conducted in Australia, North America and the UK.

This paper focuses the first two of these performance models, how they operate, and the implications for Turkish universities.

\section{National QA Systems for Higher Education}

According to UNESCO (2009), almost half of the countries in the world have now established national QA systems. However, the precise nature of the concerns over quality can vary from country to country.

In the UK, concerns about standards arose largely from grade inflation in the award of Bachelor's honours levels, indications that the universities' students spent much less time studying than their European counterparts, and questions about the dedication of academics to teaching (Gallagher, 2010).

In Europe, the Bologna Declaration (CRE, 1999) of the European Ministers of Education, European Commission, Council of Europe and UNESCO identified the need for cross-border cooperation in developing comparable QA criteria and methodologies in support of the European Higher Education Area (EHEA). The objectives of the EHEA are to achieve more comparable, compatible and coherent systems of higher education, more easily comparable degrees and credit systems, greater student and staff mobility, and more participation by international students and scholars (Ehlers, in press). The1999 Declaration led to the establishment of a comparable, compatible and coherent framework in the 'three cycles' (bachelor, master, doctorate) as well as a European Credit Transfer and Accumulation System. In 2000, the European Association for Quality Assurance in Higher Education (ENQA) was established to promote cooperation in QA in higher education in all of the Bologna signatory countries. Currently, 26 signatory countries, as well as the intergovernmental organisations involved consultatively in the Bologna Process, are members of the European Quality Assurance Register for Higher Education (EQAR).

In Turkey, the exploration and adoption of QA is also driven by a desire for international accountability, compliance with the European Higher Education Area Standards and Guidelines for Quality Assurance, and recognition of academic programmes, mobility and accord with the Bologna Process. The Ninth Development Plan (2007-2013) (Republic of Turkey Prime Ministry, 2006) observed that:

Important headway has been made in higher education, particularly in the student and instructor exchanges within the scope of the Bologna Process, the European Credit Transfer System and the diploma supplement. However, problems regarding the centralised structure and the quality of the higher education system are continuing to 
adversely influence its competitiveness and capacity to be able to respond to the requirements of the society ( $p 50$.$) .$

A strategy paper issued by the Higher Education Council (YÖK) (2007) observed that the establishment of the independent Commission for Academic Assessment and Quality Improvement in Higher Education (YÖDEK) in 2005 and the requirement that the universities prepare self-evaluation reports were important steps in establishing national and institutional QA systems. The strategy paper also pointed to the need for external review (which was non-existent at that time) in accord with the goals of the Bologna Process.

In the US, under the George W Bush administration, the Spellings Commission raised the challenge of higher education institutions being publicly accountable for learning attainment standards as a consequence of growing concerns over the quality of US higher education, the effectiveness of the self-regulating accreditation agencies and the indications of international slippage against the nation's economic competitors (Parker, in press).

Just as there are variations in the reasons for $Q A$, there are variations in the frameworks and arrangements for higher education quality validation. Parker (op cit) points to the fact that neither the US nor Canada has central regulatory bodies for QA or national qualifications frameworks. Both countries experience tensions between local and national licensing requirements and accreditation standards. This complicates matters for providers wishing to extend their reach beyond a single state or province and allows rogue operators to take advantage of the regulatory gaps. Self-assessment and peer review are the hallmarks of US accreditation processes, but these auditing systems are not transparent and do not allow for direct comparisons of institutions. Only the final decisions of the accreditation agencies are required to be made public. The Canadian post-secondary system is even less cohesive than the US system. There is no national or even regional accreditation. There is only voluntary membership of the Association of Universities and Colleges of Canada (AUCC), a nongovernmental, not-for-profit organisation representing 95 Canadian public and private not-for-profit universities and university-degree level colleges; membership of which, together with a provincial charter to grant degrees provides de facto accreditation.

Australia is also a federation, but unlike the US and Canada it does have a national QA system. Until 2011, QA was the responsibility of the Australian Universities Quality Agency (AUQA). AUQA is now in the process of being replaced by a new national regulatory and quality agency for higher education, the Tertiary Education Quality and Standards Agency (TEQSA). TEQSA will be an independent body with powers to regulate university and non-university higher education providers, monitor quality and set standards. The National Protocols for Higher Education are a key element of the national QA framework. The requirements under these Protocols must be met before new institutions can be approved to operate as Australian providers and the existing institutions must demonstrate that they continue to meet the criteria in these Protocols. TEQSA is regarded as an important part of the higher education reforms which the Federal Government announced in 2009 following the 2008 Review of Higher Education (Bradley Review). These reforms include achieving a significant increase in the proportion of the population participating in higher education, funding all Australian students admitted to a place at a funded university, funding for each university on the basis of its student enrolments, and the establishment of a national QA framework to ensure that students achieve the desired learning outcomes at the required level and that there is public confidence in the universities.

As a unitary state, the United Kingdom (UK) also has a single national QA system for higher education, albeit with some adaptations to take account of the three devolved national administrations 
of Scotland, Wales and Northern Ireland. The main agency is the Quality Assurance Agency for Higher Education (QAA), an independent body funded by the higher education institutions themselves. The QAA works closely with the major UK funding bodies, government departments and representative bodies such as Universities UK, Universities Scotland and GuildHE (an organisation representing the heads of higher education institutions). The other players in QA in the UK higher education system are the British Standards Institute, the British Accreditation Council and Open and Distance Learning Quality Council. Each university and college of higher education is held responsible for the standards of the awards it makes and the quality of the education it provides to its students. To achieve this, each institution is required to have its own internal QA procedures, guided by the QAA's Academic Infrastructure, a set of nationally agreed reference points which give all institutions a shared starting point for setting, describing and assuring the quality and standards of their higher education courses. This has four inter-related elements: the code of practice; programme specifications; subject benchmark statements; and frameworks for higher education qualifications (Kirkpatrick, in press).

Turkey complies with the the European Higher Education Area Standards and Guidelines for Quality Assurance. Ultimate responsibility for QA rests with the Council for Higher Education (YÖK) and the Inter-university Council. However, the Commission of Academic Assessment and Quality Improvement in Higher Education (YÖDEK), which is currently an associate member of the European Network for Quality Assurance in Higher Education (ENQA), is the body responsible for institutional evaluation and accreditation. YÖDEK is currently in the process of transforming into a new independent nongovernmental national agency with the involvement of the higher educational institutions and other stakeholders. This will act as a buffer organisation between YÖK, the universities and the other $\mathrm{QA} /$ accreditation agencies and stakeholders with its main responsibility being to assess the quality of the higher education institutions. The other sectoral agencies which are recognised by YÖK as responsible for accrediting programmes in accord with the learning outcomes defined within National Qualification Framework and further requirements within the related sector of study are the Association for Evaluation and Accreditation of Engineering programmes (MÜDEK), the Science, Literature, Language, History and Geography Assessment and Accreditation Association (FEDEK) and the Turkish Psychology Association (TPD). At the time of writing, applications for recognition by the Association for Accreditation of Architectural Programmes (MIAK) and the National Medical Education Accreditation Committee (UTEAK) were being processed. International accreditation is provided by the European Accreditation Programme for Engineering (EUR-ACE), the European Universities Association (EUA) Institutional Review Programme (IRP) and the US Accreditation Board for Engineering and Technology (ABET).

YÖDEK's Guide on Academic Assessment and Quality Improvement in HEIs concerns: internal assessment; external review; student participation; publication of results; international participation; an evaluation model; a list of standards and performance indicators for annual internal assessment and five-yearly external QA. YÖDEK's standards and guidelines and definitions of the processes and indicators for QA cover: academic assessment and quality improvement; strategic planning; institutional assessment (internal and external); and periodic review and improvement. All higher education institutions are required to establish Academic Assessment and Quality Improvement Boards (ADEKs) responsible for organising, coordinating and conducting the QA processes, conducting and reporting on annual internal or external assessment based upon their missions and strategic plans, and periodically reviewing, improving and implementing their strategic plans.

\section{QA in Cross-Border Higher Education}

The ideological, political and economic environment that favours global trade in products and services and the opportunities provided by information and communications technology (ICT) are leading to 
the globalisation of higher education. There are three main forms of cross-border higher education: international branch campuses, where providers teach students in other countries; partnerships in which external providers share the teaching and provision of support services with in-country partners; and distance education, which is typically online and may be reinforced by short visits by lecturers and/or in-country tuition, technical support.

The primary concern of cross-border providers is to increase their market share and profits. The reputation of cross-border higher education runs the risk of being damaged by 'commodifying' the learning experience, low-quality service provision, and 'degree mills' offering worthless qualifications. So higher education import and export requires international codes of practice and QA bodies. As Aboul-Ela (2009) observes, if education is to be seen as a market opportunity and offered as a Free Trade, as set out in the 1995 General Agreement on Trade in Services (GATS), it needs to be subject to similar quality checks for consumer protection. Marginson and McBurnie (2004) stress that QA guidelines are essential for cross-border education to uphold the prestige of universities, assure the quality of teaching and learning and protect students from becoming victims of dubious providers and practices. Sauvé (2002) suggests that since cross-border education involves national governments, these may be better agencies for regulating such provision, rather than GATS.

Some countries and institutions operate rigorous systems to protect local students against lowstandard distance and online providers. For example, Australia rules that for cross-border providers to call themselves 'universities', they must be legally established and accredited in their home countries and the academic standards of their courses/programmes must be shown to be comparable to those of their Australian equivalents. And providers applying for registration in Hong Kong must be similarly registered in their home countries, although in this case, they must offer courses, programmes and services equivalent to those offered in their home countries. To safeguard their reputations, some cross-border distance education providers also establish their own QA procedures. In exporting its distance education programmes, Indira Gandhi National Open University establishes the credibility of its partner institutions with the assistance of India's overseas High Commissions and Embassies, scrutinizes the curricula vitae of the local tutors and provides them with the necessary training, but still assesses all examination scripts centrally in order to ensure consistency in standards. At the Open University, overseas provision and partnerships are included in the Quality and Standards in the Open University documentation prepared by the Quality Office and the Curriculum Partnerships Committee is responsible for all regulatory matters relating to these partnerships and their approval by the Curriculum and Awards Boards.

However, such arrangements are the exception than the rule. Despite the increase in national QA and accreditation bodies for higher education, few of these directly address QA in cross-border provision and there is still great need to improve the monitoring and control of such programmes. Cross-border programmes can be poorly conceived, inter-institutional agreements/contracts can be weakly framed, and there can be inadequate governance and QA of their export and import. There can also be insufficient understanding of the needs, expectations, cultures and circumstances of the cross-border students, over-reliance upon inexperienced local partners, and difficulties in providing adequate crossborder resources, staff, library and support services.

To help strengthen QA and accreditation in this area, the Organisation for Economic Co-operation and Development has developed Guidelines for Quality Provision in Cross-border Higher Education (OECD, 2005). These Guidelines do not seek to supersede individual countries' authority to regulate the QA and accreditation of their own higher education systems but to involve the collaboration of both the sending and receiving countries. They are designed to protect students from the risks of misinformation, low-quality provision and qualifications of limited validity. They advocate that 
recognition procedures should be transparent, coherent, fair and reliable, should impose as little burden as possible on mobile professionals, and should encourage national QA and accreditation agencies to strengthen their international cooperation. These Guidelines are non-binding, but they are now being followed by the following regional QA bodies:

- Arab Network for Quality Assurance in Higher Education (ANQAHE).

- ASEAN Quality Assurance Network (AQAN).

- Asia-Pacific Quality Network (APQN).

- Caribbean Network for Quality Assurance in Tertiary Education (CANQATE).

- Central and Eastern European Network of Quality Assurance Agencies in Higher Education (CEEN).

- Eurasian Quality Assurance Network (EAQAN).

- European Network for Quality Assurance in Higher Education (ENQA).

- European Consortium for Accreditation (ECA).

- Ibero-American Network for Quality Assurance in Higher Education (RIACES).

- Quality Assurance Network for African Higher Education (AfriQAN).

All of these regional networks have also signed memorandums of understanding with the International Network for Quality Assurance Agencies in Higher Education, a world-wide association of over 200 organisations active in the theory and practice of quality assurance in higher education, which has itself developed Guidelines of Good Practice in Quality Assurance. (INQAAHE, 2007)

Turning now to Europe, in 2003, the Ministers of the signatory states charged the European Network for Quality in Higher Education (ENQA) with developing an agreed set of standards, procedures and guidelines on QA for higher education, taking into account the experience of other QA associations and networks. ENQA's Standards and Guidelines for Quality Assurance in the European Higher Education Area (ENQA, 2009) contains standards for:

- QA within institutions.

- External QA of institutions.

- External QA agencies.

These Guidelines cover policies and procedures for reviewing and reporting on:

- Institutions.

- Programmes and awards.

- Students.

- Teaching staff.

- Learning resources.

- Student support.

- Information systems and public information.

ENQA stresses that while these Guidelines provide the common framework and drivers for change, the principle responsibility for QA must remain with the universities themselves, and that this requires the development of a quality culture with managers and staff who understand and believe in continuous improvement.

\section{QA Issues in Turkish Higher Education}

Traditionally, YÖK initially assessed and licenced university courses and then entrusted the institutions thereafter. In the mid 1990s, YÖK attempted to introduce a more systemic and comprehensive QA system in line with other OECD and EU countries, but a substantial number of individuals expressed their reservations about such a practice and its appropriateness to Turkey, and these moves were abandoned in the face of stiff opposition from the universities (Borahan, n.d.; Ergüder, 2006). 
Borahan (op cit) observes that there is a strong correlation between a country's competitiveness and the quality of its higher education systems and that as the EU proceeds with formal negotiations and considers whether and how Turkey's accession process should proceed, it is inevitable that a systemic and comprehensive QA system should be adopted in line with the National Qualifications Framework for Lifelong Learning. However, the achievement of such a system calls for a major shift of mind-set right across the Turkish higher education system. Kaplan (2009) reports that while the Academic Assessment and Quality Improvement Boards in some institutions are performing well, others are less effective, largely due to lack of buy-in by the academic staff, and many QA processes are still at an early stage of development or limited to piloting in certain departments. Kaplan also notes that while the number of higher education institutions has doubled in recent years and some of the newer universities are making strong efforts to catch up with their more established counterparts, QA is still low on their agendas. He also observes that among the universities making the greatest advances in QA are the established engineering-based universities, with their longer experience of working with ABET and MUDEK. Ergüder (op cit) believes that competition can be the main driving force in QA in Turkish universities, as evidenced by the increasing number of state institutions that are applying for the European University Association (EUA) QA process, a voluntary process funded by the universities themselves.

However, at the time of writing, change was in the air. The Council of Europe (2011) was launching a new initiative to align the Turkish higher education system with the EHEA and to help improve national and institutional capacity in regard to:

- The National Qualification Framework (NQF).

- QA.

- The recognition of qualifications, including recognition of prior learning.

- Membership of ENQA and EQAR.

YÖK's website (https://basin.yok.gov.tr/?page=duyurular\&v=read\&i=248) states that:

The need for re-structuring the higher education system is on the agenda because of the fact that when the Council was established in 1981, there were only 27 universities but this is almost 6fold today [165]. This quantitative growth brought new responsibilities to the Council. Moreover failing to accomplish the necessary theoretical and institutional adjustments to respond to the internal and external trends is increasing the 'cost of the delayed reforms' . . . The Council is working towards the structuring the systems on the basic principles of:

- Diversity.

- Institutional autonomy and accountability.

- Performance assessment and competition.

- Financial flexibility and multi source income structure.

- Quality assurance.

And a new government had just been elected, which might lead to changes in the higher education system. Given these developments, it may be timely to consider the ramifications regarding QA.

\section{Issues for Consideration}

The following section raises a number of questions for consideration by those embarking on QA in higher education institutions. The readers are invited to consider whether or not they agree with the various points raised. 


\section{Why should universities measure their performance and outcomes?}

As Marginson (2004) observes, competition in higher education is now a fact of life. Students compete for entry into universities. Universities compete for the best students. Governments encourage a greater measure of competition between universities. And with globalisation, national and world standards are taken into account and universities want to rank highly in teaching and research quality.

There are now many kinds of higher education provider, and public, private and online universities are situated in an open information environment in which national borders are routinely crossed. Furthermore, as high quality open courseware becomes increasingly available worldwide, Sharma (2011) asks: How will the standards of local institutions' courses and pedagogy measure up against the MIT Open Courseware, the Connexions Project of Rice University, the hundreds of universities, including the UK Open University, that are making their programmes available iTunes $U$ and YouTube? And what happens if these evolve into superior global open repository? How then will universities differentiate themselves - by brand, by the quality of their teaching, support services and pastoral care, by their evidence of superior learning outcomes or by their capacity to customise and/or add to such material?

\section{What is meant by quality and $Q A$ in the university context?}

Quality means different things in different contexts. It can signify excellence (achieving something exceptional and distinctive), or consistency and flawnesses in outcomes, or fitness for purpose (fulfilling customers' requirements, needs or desires), or value for money (achieving the same outcomes at lower cost or better outcomes at the same cost), or transformation, improvement and enhancement.

QA can be concerned with different outcomes: ensuring stakeholder satisfaction with products and services, or comparisons of standards with those of other organisations, or continuous improvement in the face of competition (Harvey \& Green, 1993).

QA in higher education can also seek evidence of different kinds of outcomes: learning effectiveness (improved learning, retention rates, graduation rates, employability, commitment to lifelong learning, etc.); stakeholder satisfaction (the value of the students' experience, qualifications, knowledge, attitudes and skills to themselves, their employers, the wider community and the national economy); educational and economic competitive advantage (institutional, national and international); value-formoney; and the long-term reputation and viability of institutions, programmes /courses.

As Kirkpatrick (op cit) observes, these different definitions and emphases of quality can result in misalignments of purpose and focus in quality reviews and processes and disagreement between the different stakeholders on the criteria and standards by which institutions should be assessed. She also notes that the more powerful stakeholder's perspective is usually the one that prevails.

\section{Is QA really worth all the effort and cost?}

Referring specifically to Australian higher education, although the comments apply in other jurisdictions, Coaldrake (2011) observes that:

More students and new providers mean that quality assurance is essential. . . It is appropriate that all universities will be required to prove they are worthy of the name, though history suggests there are diminishing returns to probing ever further into what they do and diverting resources in the process. However, it is particularly important to have a strong filter for newcomers... 
However, the technical process of audit, which will be significantly bolstered with the establishment of a national regulator, will not produce quality in the absence of adequate resourcing.

So here's the rub. Governments are pressing the universities to evidence quality in their operations just at a time when in many cases, they are reigning in their funding for the public institutions. It may be felt that the bureaucracy, paperwork, time and additional costs of external and/or internal QA are untenable. So the cost benefits of QA need to be evidenced. This entails careful consideration of the total quality costs of preventing, finding, and correcting faults and failures in systems, products and services. The total quality costs comprise:

- Prevention costs - the costs incurred in avoiding defects in organisational systems, programmes and services at the very outset. This is arguably the prime role of QA.

- Appraisal costs - the costs involved in the in-process and final inspection/testing of systems, products and services to assure that these conform to the required standards and prevent failure costs before these products and services enter the public domain.

- Failure costs - systems, products or services not conforming to requirements or user needs. These can be internal (the costs of rectifying deficiencies discovered before delivery to the customers) and/or external (the costs incurred in remedying the defects experienced by the customers). The later these failures are detected, the more costly their remediation. The costs incurred at this stage include re-working or abandoning systems, products and services, the opportunity costs (the costs of not implementing alternative systems, products and processes) and the costs of losing trust, reputation and goodwill (Juran, 1979).

Pirozzi (n.d.) argues that all of the above costs can be reduced through the adoption of smarter QA systems but admits that capturing the data needed for QA can be difficult and expensive, so it is also important to determine whether the benefits of tracking the total quality cost will provide sufficient return on investment to make paying for the implementation of the QA system worthwhile.

\section{Should conventional higher education and open and distance education and e-learning be treated differently?}

Bates (2010) tells of a lecturer in one university that he visited saying: 'I have the same feeling about QA processes as Goebbels had for culture: whenever I hear the words I reach for my gun'. At another institution, he was told, 'We put in place a QA process for online learning that was so hideously bureaucratic, none of the faculty wanted to do it.' When he asked whether there was a similar process for face-to-face teaching and learning courses, the answer was, 'Of course not.' Bates believes that because e-learning is still often under a cloud of suspicion, this can give rise to more demanding forms of QA than are applied to conventional teaching and learning.

The jury is still out on whether distance, online and face-to-face education should be judged by the same criteria and methods. The US Council for Higher Education and Accreditation (CHEA, 2002) holds that the new types of provider and teaching and learning methods present new challenges to accreditation standards, policies and procedures, so accrediting organisations should not only ensure that the standards of the distance courses are commensurate with those of conventional courses, but should subject the unique features of distance education to particular scrutiny.

On the other hand, the UK's Quality Assurance Agency does not identify, nor does it consider, the provision of, distance education separately from the provision of on-campus education. However, its 
codes of practice do include a section on the academic management of learning delivered, supported and/or assessed through flexible and distributed arrangements by an institution or collaborating institutions. It is clear that distance education methodologies are included in this, as the QAA defines distributed and flexible learning as learning, teaching and assessment that do not require a student's place of study to be physically located within the institution or the assessment of that student's achievement to occur at the location of the awarding institution (Kirkpatrick, in press).

David Woodhouse (2006), President of INQAAHE, holds that the criteria for judging inputs and processes and their correlation with quality outcomes should be similar both for face-to-face and distance cross-border education programmes but allows that because teachers, students and resources are dispersed or online, in the course of assessing their quality, different questions may need to be asked and different enquiry methods may need to be employed.

While many institutions now accept that online methods can improve learning, too many politicians, policy-makers, institutions and teaching departments still place too much faith in the technology. Marshall (2009) suggests that when employing e-learning, the QA standards should:

- Reflect the diversity of student learning capabilities and desired outcomes.

- Evolve to meet the challenges of new forms of technology and new types of pedagogy and stimulate further discussion, application and research.

- Be enablers of effective practice rather than constraints on creativity.

- Reflect an evidence base of effective teaching practice and research into ways of improving student learning.

- Be expressed in a way that enables efficient determination of compliance and an ability to benchmark or document that compliance.

- Assist institutions in identifying areas in need of development and strategic decisions about elearning directions for the institution as a whole.

Ehlers (in press) argues that with the advent of 'e-learning 2.0', online learning ceases to be a case of institutional or commercial providers 'delivering' learning that is then 'consumed' by the students. It becomes a platform where learning is created by students as well as the lecturers and programme makers, and this requires different questions to be asked, different objects and processes to be evaluated, different quality criteria to be applied during the QA process, and different approaches to be adopted in seeking improvement.

\section{Why should students be brought into the QA process?}

It is a tenet in the corporate world that organisations should understand and address their customers' needs. Harry Gordon Selfridge, who established the famous London store, and Marshall Field, whose store in Chicago was another shopping icon, both used the phrase 'the customer is always right' in marketing their companies. However, the applicability of this model to today's higher education is open to question when learning does not simply comprise products and services delivered to the learner, but as Ehlers (2004) argues, and particularly in e-learning, the knowledge, understanding and skills are negotiated and co-developed by the learners and the teachers. Also, as Jung (in press) observes, a customer focus is important, but if every care has been taken to ensure quality in the instructional design, learning environment and learner support, and the learner still fails to contribute, is abrasive, and spoils everything for the other learners and the teachers, then in that case, the customer is wrong.

Nonetheless, it is important to heed and take account of the learners' perceptions and opinions in regard to QA. It cannot be taken for granted that they perceive the quality of the teaching and 
learning in the same ways as the providers. As Jung (op cit) observes, surprisingly little account is taken of students' views in many institutions that claim to be 'learner-centred'. At the institutional level, it is important that QA should include:

- Student surveys and discussion groups for students to report on their experiences with and opinions on the courses/programmes, teaching, learning, assessment, etc.

- Focus groups wherein staff, students and employers can share their experiences and ideas on learning processes and learning outcomes.

- Discussions with students about assignments, examinations and assessment in order to identify strengths and weaknesses in the students and these processes.

- Student involvement in programme/course team planning meetings, etc.

It is important to note that in the European context, the European Students' Union is a consultative member to the Bologna Process, representing European students in various working groups, and its Academic Affairs Committee deals with such issues as the European Credit Transfer and Accumulation System and qualification frameworks. Also, that in the Turkish context, YÖDEK comprises nine academic members elected by the Inter-University Board and one representative of the National Student Council.

\section{Should QA should be mandatory, externally managed and concerned with accountability? Or should it be voluntary, conducted internally and focused on developing a culture of quality?}

Universities have long enjoyed a tradition of autonomy and being accountable for their own standards and performance. So intervention by governments and QA agencies into a domain they regard as their own prerogative understandably creates tensions, and especially where there are attempts to prescribe standards, exact compliance and apply sanctions such as loss of registration or eligibility for funding (Gallagher, op cit).

Some QA regimes adopt coercive stances in their auditing methods. Others place more weight on a consensual approach. It has been repeatedly demonstrated that external QA processes are most effective when they encourage and support institutions in devising and monitoring compliance with their own self-regulatory standards, engaging in continuous improvement and enhancement and the creation of a culture of quality rather than imposing heavily regulated compliance and control (Chalmers et al, 2008).

Arguing for a culture of quality and a focus on self-evaluation and improvement rather than accountability Kanwar (2010) suggests that institutions need to seek evidence to answer the following questions:

- How effectively do they communicate with their stakeholders?

- How well do they provide the outcomes that its stakeholders need and value?

- How effectively do they engage with local and international communities?

- How effective are their innovative and creative responses to a changing environment?

- How effectively do they develop the capacity of their managers and staff to provide valued outcomes for their stakeholders?

- How well do they monitor and improve their performance?

\section{Should QA be input-based or outcomes-based?}

YÖDEK's current standards and guidelines suggest that self-assessment by the Turkish universities should focus on:

- Mission. 
- Inputs.

- Institutional qualities and characteristics.

- Educational processes.

- Research and development processes.

- Implementation and service processes.

- Administrative and support processes.

- Managerial characteristics.

- Outcomes.

While QA systems worldwide focus on the management of delivery, support and evaluation of teaching, learning and assessment, the trend is to regard the quality of the outcomes as of greater significance than the inputs. To take but one example, the UK's QAA frames its expectations and benchmarks around outcomes.

Outcomes can be expressed as key performance indicators (KPIs) or as critical success factors (CSFs). KPIs are those financial and non-financial measures that help an institutions measure progress towards their stated visions, missions and organisational goals/strategic objectives. They allow management to judge institutional or departmental performance by clear criteria. They enable teams to work together to a common set of measurable goals. And they provide a quick way of finding answers to such questions as: 'Where are we ahead or behind?', 'How far ahead or behind are we?' and 'Where are we weakest and where are we strongest?' in order to arrive at clear and accurate measures to support planning and operations.

CSFs are those elements that are vital for given strategies to be successful: for example, introducing new courses or programmes, gaining new funding sources, achieving revenue growth or greater profit margins, attracting more or better students, forming new partnerships, entering new markets, reassuring particular stakeholders of the quality of policies, procedures, products and services, increasing the intellectual capital of the institution/staff, improving institutional capacity to appoint and retain the very best staff, or assuring institutional capacity to survive/advance in the face of change

Such outcomes can be assessed qualitatively (descriptively) and/or quantitatively (numerically). An analytic rubric can be used for formative or summative evaluation of policies, procedures, products, services and other activities, as shown in Table 1.

Table 1: An analytic rubric for judging the achievement of key performance indicators or critical success factors

\begin{tabular}{|c|c|c|c|c|c|c|}
\hline $\begin{array}{l}\text { KPIs/ } \\
\text { CSFs }\end{array}$ & $\begin{array}{l}\text { Exemplary } \\
\text { (4 points) }\end{array}$ & $\begin{array}{l}\text { Good } \\
\text { (3 points) }\end{array}$ & $\begin{array}{l}\text { Developing } \\
\text { (2 points) }\end{array}$ & $\begin{array}{l}\text { Unsatisfactory } \\
\text { (1 point) }\end{array}$ & $\begin{array}{l}\text { Unmet } \\
\text { (0 point) }\end{array}$ & $\begin{array}{l}\text { Total } \\
\text { score }\end{array}$ \\
\hline $\begin{array}{l}\text { KPI/CSF } \\
\# 1\end{array}$ & $\begin{array}{l}\text { Statement } \\
\text { on why the } \\
\text { outcome is } \\
\text { considered } \\
\text { exemplary }\end{array}$ & $\begin{array}{l}\text { Statement } \\
\text { on what is } \\
\text { good about } \\
\text { the } \\
\text { outcome }\end{array}$ & $\begin{array}{l}\text { Statement } \\
\text { on the } \\
\text { progress } \\
\text { being made } \\
\text { towards } \\
\text { achieving } \\
\text { the outcome }\end{array}$ & $\begin{array}{l}\text { Statement on } \\
\text { why the } \\
\text { outcome is } \\
\text { considered } \\
\text { unsatisfactory }\end{array}$ & $\begin{array}{l}\text { Statement } \\
\text { on how and } \\
\text { why the } \\
\text { outcome is } \\
\text { not being } \\
\text { met }\end{array}$ & 01234 \\
\hline $\begin{array}{l}\text { KPI/CSF } \\
\# 2\end{array}$ & $\begin{array}{l}\text { Statement } \\
\text { on why the } \\
\text { outcome is } \\
\text { considered } \\
\text { exemplary }\end{array}$ & $\begin{array}{l}\text { Statement } \\
\text { on what is } \\
\text { good about } \\
\text { the } \\
\text { outcome }\end{array}$ & $\begin{array}{l}\text { Statement } \\
\text { on the } \\
\text { progress } \\
\text { being made } \\
\text { towards the } \\
\text { achieving } \\
\text { outcome }\end{array}$ & $\begin{array}{l}\text { Statement on } \\
\text { why the } \\
\text { outcome is } \\
\text { considered } \\
\text { unsatisfactory }\end{array}$ & $\begin{array}{l}\text { Statement } \\
\text { on how and } \\
\text { why the } \\
\text { outcome is } \\
\text { not being } \\
\text { met }\end{array}$ & 01234 \\
\hline
\end{tabular}




\begin{tabular}{|c|c|c|c|c|c|c|}
\hline $\begin{array}{l}\text { KPIs/ } \\
\text { CSFs }\end{array}$ & $\begin{array}{l}\text { Exemplary } \\
\text { (4 points) }\end{array}$ & $\begin{array}{l}\text { Good } \\
\text { (3 points) }\end{array}$ & $\begin{array}{l}\text { Developing } \\
\text { (2 points) }\end{array}$ & $\begin{array}{l}\text { Unsatisfactory } \\
\text { (1 point) }\end{array}$ & $\begin{array}{l}\text { Unmet } \\
\text { ( } 0 \text { point })\end{array}$ & $\begin{array}{l}\text { Total } \\
\text { score }\end{array}$ \\
\hline $\begin{array}{l}\text { KPI/CSF } \\
\# 3\end{array}$ & $\begin{array}{l}\text { Statement } \\
\text { on why the } \\
\text { outcome is } \\
\text { considered } \\
\text { exemplary }\end{array}$ & $\begin{array}{l}\text { Statement } \\
\text { on what is } \\
\text { good about } \\
\text { the } \\
\text { outcome }\end{array}$ & $\begin{array}{l}\text { Statement } \\
\text { on the } \\
\text { progress } \\
\text { being made } \\
\text { towards the } \\
\text { achieving } \\
\text { outcome }\end{array}$ & $\begin{array}{l}\text { Statement on } \\
\text { why the } \\
\text { outcome is } \\
\text { considered } \\
\text { unsatisfactory }\end{array}$ & $\begin{array}{l}\text { Statement } \\
\text { on how and } \\
\text { why the } \\
\text { outcome is } \\
\text { not being } \\
\text { met }\end{array}$ & 01234 \\
\hline
\end{tabular}

A similar approach may be used for judging the quality of a QA system, as shown in Table 2.

Table 2: An analytic rubric for judging the quality of a QA system

\begin{tabular}{|c|c|c|c|c|c|c|}
\hline $\begin{array}{l}\text { Stated } \\
\text { outcomes }\end{array}$ & $\begin{array}{l}\text { Policies } \\
\text { and } \\
\text { procedures }\end{array}$ & $\begin{array}{l}\text { Monitoring } \\
\text { systems }\end{array}$ & $\begin{array}{l}\text { Performance } \\
\text { standards }\end{array}$ & $\begin{array}{l}\text { Response to } \\
\text { problems } \\
\text { and } \\
\text { shortcomings }\end{array}$ & $\begin{array}{l}\text { Action } \\
\text { needed }\end{array}$ & $\begin{array}{l}\text { Total } \\
\text { score }\end{array}$ \\
\hline $\begin{array}{l}\text { Outcome } \\
\text { \#1 }\end{array}$ & $\begin{array}{l}\text { Statement } \\
\text { on quality of } \\
\text { policies and } \\
\text { procedures }\end{array}$ & $\begin{array}{l}\text { Statement } \\
\text { on quality of } \\
\text { monitoring } \\
\text { procedures }\end{array}$ & $\begin{array}{l}\text { Statement on } \\
\text { quality of } \\
\text { performance } \\
\text { standards }\end{array}$ & $\begin{array}{l}\text { Statement on } \\
\text { steps taken to } \\
\text { rectify } \\
\text { problems and } \\
\text { shortcomings }\end{array}$ & $\begin{array}{l}\text { Statement } \\
\text { on action } \\
\text { needed }\end{array}$ & 01234 \\
\hline $\begin{array}{l}\text { Outcome } \\
\# 2\end{array}$ & $\begin{array}{l}\text { Statement } \\
\text { on quality of } \\
\text { policies and } \\
\text { procedures }\end{array}$ & $\begin{array}{l}\text { Statement } \\
\text { on quality of } \\
\text { monitoring } \\
\text { procedures }\end{array}$ & $\begin{array}{l}\text { Statement on } \\
\text { quality of } \\
\text { performance } \\
\text { standards }\end{array}$ & $\begin{array}{l}\text { Statement on } \\
\text { steps taken to } \\
\text { rectify } \\
\text { problems and } \\
\text { shortcomings }\end{array}$ & $\begin{array}{l}\text { Statement } \\
\text { on action } \\
\text { needed }\end{array}$ & 01234 \\
\hline $\begin{array}{l}\text { Outcome } \\
\text { \#3 }\end{array}$ & $\begin{array}{l}\text { Statement } \\
\text { on quality of } \\
\text { policies and } \\
\text { procedures }\end{array}$ & $\begin{array}{l}\text { Statement } \\
\text { on quality of } \\
\text { monitoring } \\
\text { procedures }\end{array}$ & $\begin{array}{l}\text { Statement on } \\
\text { quality of } \\
\text { performance } \\
\text { standards }\end{array}$ & $\begin{array}{l}\text { Statement on } \\
\text { steps taken to } \\
\text { rectify } \\
\text { problems and } \\
\text { shortcomings }\end{array}$ & $\begin{array}{l}\text { Statement } \\
\text { on action } \\
\text { needed }\end{array}$ & 01234 \\
\hline
\end{tabular}

So what should these outcomes be primarily concerned with? The Higher Education Funding Council of England (HEFCE, 2005) argues that the most powerful quality indicator for any institution or programme is whether the students have actually developed the pre-specified competencies and that QA should therefore place an emphasis on this over any other variables. Ján Figel', the European Commissioner for Education, Training, Culture and Youth, observes that many of the academic programmes of the European Universities are not adapted to the needs of the labour market, and the European Commission is asking for more accountable ways of universities to inform their potential students about the employability of the degrees offered so that they can make better choices (Myklebust, 2009). Worldwide, surveys show that generic attributes such as problem solving, data analysis, computing skills, numeracy, and the capacity to work and communicate effectively in teams are valued highly by employers. Universities are now being encouraged to place emphasis on these attributes in order to prepare their students for the working environment, to be a more employable and to increase employer satisfaction. 
A Turkish study by Deliveli, et al (2007) revealed a mismatch between the skills employers are seeking and the skills that many graduates possess. Foreign language skills, especially English, computing skills, analytical skills, social, behavioural and communications skills were seen as the most important in almost all sectors, cities and occupations. Traditional firms emphasised the need for behavioural skills, such as loyalty and trustworthiness, and modern firms expressed the need for analytical skills. These findings would suggest that QA in Turkish higher education should be very much concerned with generic outcomes.

OECD is currently engaged with around 150 universities in 15 OECD member countries to see whether an Assessment of Higher Education Learning Outcomes (AHELO) instrument can be developed to test what university students know and can do upon graduation (OECD, 2011). It is recognised that students' education is greatly influenced by the quality and support of the teachers, the available resources and whether or not the environment is conducive to learning. The aim is therefore to assess both the inputs (what the students bring to their degree studies) and the outputs (what they graduate with). Value-added or learning gain will not be measured during the pilot, but the methodologies and tools for evaluating this will be explored in subsequent work if the initial study yields positive results. If fully implemented, AHELO could become a tool for universities to assess and improve their teaching, students to make better choices in selecting institutions, policy-makers to ensure that the considerable amounts spent on higher education are well spent, and employers to know if the skills of the graduates entering the job market match their needs.

The value-added dimension is also important in QA. Perceptions of quality in universities are often based on the ages, exclusivity, limited enrolments and small class sizes of the institutions, rather than their actual performance. Traditionally, universities have operated with a ' quality-in' model, determining which students to admit on the basis of matriculation and thus helping the already advantaged gain further privileges and opportunities, and achieving high performance rates. More 'open' universities employ a 'quality-out' model, being less restrictive in their entry procedures and working to help more students with latent or less conventional abilities (the so-called late developers) to realise their potential. The quality of outcomes needs to judged by the value-adding of the latter approach. Developing the attitudes, knowledge and skills of learners in rural, remote or disadvantaged communities which lack a tradition of formal education or access to the resources taken for granted in more privileged settings and improving the non-completion and examination rates are extremely important outcomes for national development.

\section{How might we develop an institutional QA system?}

Jung (2005) suggests that there are essentially three models for organising QA in universities:

- Centralised, in which QA is managed by designated offices in accord with national and / or institutional policies, procedures and criteria.

- Collective, in which various boards, councils and committees have responsibility for the different levels, stages and aspects of QA.

- Dispersed, in which responsibility for the various aspects of QA is delegated to different units.

A strong case for centralising QA is made by Belawati, Zuhairi and Wardani (in press), who detail how QA was introduced into Universitas Terbuka (UT) in Indonesia, one of the world's mega-universities. UT's 2001-2005 Operational Plan expressed the need for QA and the establishment of a QA Committee answerable to the Rector and Vice Rectors charged with developing a QA framework. Referring to the Asian Association of Open Universities QA framework and after university-wide consultation, the QA Committee developed a QA Policy Manual comprising 107 best practice statements regard to: policy and planning; human resource recruitment and development; 
management and administration; programme design and development; course design and development; teaching and learning; learning support; learner assessment; and media for learning. This Manual was then converted into a self-evaluation instrument by adding quality indicators and using 1-4 Likert Scales in order to gain university-wide self-judgments on the extent to which these quality indicators were being fulfilled, to measure attitudes towards these best practice statements and to gather opinion on the priorities for improvement. Drawing upon these findings, teams of academic and administrative staff then developed Job Manuals which set out performance standards/intended outcomes for all systems and procedures and the competencies and resources needed to achieve these. Thus the process was initiated 'top down' but implemented by many participants reporting upwards. By Rector's Decree, the QA framework and Job Manuals were then formally adopted, a QA centre was established, and the first year of implementation was known as the 'Year of the Spirit of the Quality Assurance'.

In the UT QA system, annual internal reviews are conducted by 'drilling down' to test for consistency. Where targets are found to be unmet, systems and procedures are re-appraised to determine whether the problems lie with these or with individuals. Under-performers receive advice and training in how to achieve the expected quality outcomes. Quality performers receive rewards, incentives or compensations in the following year. These procedures are conducted in the spirit of continuous improvement. They also help to feed into external assessment and accreditation by the National Accreditation Board for Indonesian Higher Education International Council. Performance appraisal by the International Organisation for Standardisation (ISO) and Open and Distance Education Standard Agency also enables UT to benchmark its processes and outcomes against similar institutions nationally, regionally and globally.

\section{Conclusion}

The World Bank (2007) reports that education and skill levels in Turkey lag international standards, including those of the EU, and that international tests show poor performance for many students and low participation in secondary and tertiary education by international standards. Significantdisparities also exist in educational quality and access by gender, social and economic group and geographic location. So setting higher benchmarks should be the aim of all of those responsible for higher education, not simply ensuring that current standards are being met.

Quality can never be taken for granted. It has to be continually worked for. Recent quality problems experienced by firms such as Toyota, Honda, Boeing and Rolls Royce, the loss of market leadership by firms such as Sony and the filing for bankruptcy by organisations such as Japan Airlines have been attributed to complacency bred from success or a 'too-big-to-fail' attitude, a tendency to stick with the status quo MSN (2010), and a lack of care in the QA inspection processes and personnel (Productivity Press, 2008). It is salutary to note that some of these failures occurred in Japan - the home of QA.

The lessons are clear. Quality in higher education can be assured only where policies, regulations and quality controls intersect with all practices and at every stage and where everyone in the process is properly trained in, and committed to, achieving the highest quality. QA in higher education calls for academic rigour, the application of valid measurement tools, and reliable evidence of the quality of what the students learn, how they learn, and the benefits of their learning - not simply ticking boxes. And those who are concerned to introduce new methods and new technologies must show that their systems and methods are superior to the more conventional systems and well suited to the needs of the knowledge society and Information Age. 


\section{References}

Aboul-Ela, B. (2009). Quality assurance at a distance [Powerpoint]. Keynote presentation at the Biennial INQAAHE Conference, 30 March-2 April 2009 hosted by the Commission for Academic Accreditation, Ministry of Higher Education in the United Arab Emirates. Retrieved from www.inqaahe.org/main/conferences-and-fora/inqaahe-2009-conference

Bates, T. (2010, June 22). In search of quality in e-learning. Retrieved from www.tonybates.ca/2010/06/22/in-search-of-quality-in-e-learning

Belawati, T., Zuhairi, A. \& and Wardani, I G.A.K. (in press). Quality assurance in a mega-university: Universitas Terbuka. In I. Jung \& C. Latchem (Eds.) Quality Assurance and Accreditation in Distance Education and e-learning: Models, policies and research. New York \& London: Routledge.

Borahan, N. G. (n.d.). Developing a system of quality assurance for the higher education sector in Turkey. Istanbul: Doğuş University. Retrieved from journal.dogus.edu.tr/13026739/2000/cilt\%5B1\%5D/sayi1/M00003.pdf

Chalmers, D., Lee, K., \& Walker, B. (2008). International and National Indicators and Outcomes of Quality Teaching and Learning Currently in Use. Strawberry Hills, NSW, Australia: Carrick Institute for Learning and Teaching in Higher Education Ltd. Retrieved from www.altc.edu.au/teaching-qualityindicators

CHEA (2002). Accreditation and Assuring Quality in Distance Education. Washington: Council for Higher Education and Accreditation. Retrieved from http://www.chea.org/Research/AccredDistance-5-9-02.pdf

Coaldrake, P. (2011). A tricky balancing act. Higher Education. The Australian, May 18, 2011. Retrieved from www.theaustralian.com.au/higher-education/opinion-analysis/a-trickybalancing-act/story-e6frgcko-1226057730387

Council of Europe (2011). EU/CoE Programme: Aligning Higher Education in Turkey with the European Higher Education Area. Call for Tender for Long-Term Consultant (Reference 2011 AO 24)

Strasbourg: Council of Europe. Retrieved from www.coe.int/t/dc/files/CallForTenders/apof2011AO24_en.asp

CRE (1999). The Bologna Declaration on the European space for higher education: an explanation. The Confederation of EU Rectors' Conferences and the Association of European Universities. Retrieved from ec.europa.eu/education/policies/educ/bologna/bologna.pdf

Deliveli, E., Acar, O., Aydın, İ, Bozkurt, Ö., Çağlar, E. Çetin, C., Erdem, A., Fazıı̆ı̆lu, Ö., Haşar, Ç., Kalkan, S. Koyuncu, E., Kuş, S., Pamuk, H., Songülen, Z., Tan, Ç \& Tuncay, U. (2007). Higher Education and the Labor Market in Turkey. Part of a Higher Education Sector Study of the World Bank prepared by a Team of Economic Research Foundation of Turkey. Retrieved from siteresources.worldbank.org/EXTECAREGTOPEDUCATION/Resources/4446071192636551820/TEPAV.pdf

Ehlers, U. (2004). Quality in e-learning from a learner's perspective. Presentation at the Third EDEN Research Workshop 2004, Oldenburg, Germany. Retrieved from http://www.eurodl.org/materials/contrib/2004/Online_Master_COPs.html

Ehlers, U-D. (in press). Quality assurance policies and guidelines in European distance and e-learning. In I. Jung \& C. Latchem (Eds.) Quality Assurance and Accreditation in Distance Education and e-learning: Models, policies and research. New York \& London: Routledge.

ENQA (2009). Standards and Guidelines for Quality Assurance in the European Higher Education Area - 3rd edition. Helsinki, Finland: European Association for Quality Assurance in Higher Education. Retrieved from www.enqa.eu/files/ESG_3edition\%20(2).pdf

Ergüder, Ü. (2006). Accreditation and quality assurance in Turkey, [Powerpoint Presentation] at CHEA 2006 International Committee Meeting, 26 January 2006, San Francisco, CA. Retrieved from www.chea.org/international/commission2006/UUrguder_IC012606.pdf 
Fisher, D., Rubenson, K., Rockwell, K., Grosjean, G., \& Atkinson-Grosjean, J. (2000). Performance Indicators: $A$ summary. A study funded by the Humanities and Social Science Federation of Canada/Fédération canadienne des science humaines et socials. Retrieved from www.fedcan.ca/english/fromold/perf-ind-impacts.cfm

Gallagher, M. (2010). The Accountability for Quality Agenda in Higher Education. Canberra, ACT: Group of Eight Australia. Retrieved from www.go8.edu.au/university-staff/go8-policy-_and_analysis/2010/the-accountability-for-quality-agenda-in-higher-education

Harvey, L., \& Green, D. (1993). Defining quality. Assessment and Evaluation in Higher Education, $18(1)$, pp.9-34.

HEFCE (2005). HEFCE Strategy for e-learning. Bristol, UK: Higher Education Funding Council of England) Retrieved from http://www.hefce.ac.uk/pubs/hefce/2005/05_12/

Higher Education Council (YÖK) (2007). Strategy Paper on Higher Education in Turkey. Ankara: YÖK. Retrieved from www.yok.gov.tr/content/view/557/238/

INQAAHE (2007). Guidelines of Good Practice in Quality Assurance. The Hague, The Netherlands. International Network for Quality Assurance Agencies in Higher Education. Retrieved from www.inqaahe.org/admin/files/assets/subsites/1/documenten/1231430767_inqaahe--guidelines-of-good-practice[1].pdf

Jung, I. (2005). Quality assurance survey of mega-universities and selected distance teaching institutions, In C. McIntosh \& Z. Voroglu (Eds.) Lifelong Learning and Distance Higher Education, (pp. 79-96). COL Perspectives on Distance Education Series. London \& New York: Routledge.

Jung, I. (in press). Learners' perceptions and opinions of quality assurance. In I. Jung \& C. Latchem (Eds.) Quality Assurance and Accreditation in Distance Education and e-learning: Models, policies and research. New York \& London: Routledge.

Juran, J. M. (1979). Quality Control Handbook. New York: McGraw-Hill.

Kanwar, A. (2010, April). Review and Improvement Model (COL RIM). Paper presented the meeting of the University of Guyana, Georgetown. Retrieved from www.col.org/SiteCollectionDocuments/Kanwar100409_COLRIM.pdf)

Kaplan, M. (2009). Quality assurance structure and system in higher education system of Turkey. Ankara: YÖK. Retrieved from www.mqa.gov.my/aqaaiw/.../Turkey/QA\%20TURKEY\%20V3.pdf

Kirkpatrick, D. (in press). Quality assurance and accreditation for distance education in the United Kingdom. In I. Jung \& C. Latchem (Eds.) Quality Assurance and Accreditation in Distance Education and e-learning: Models, policies and research. New York \& London. Routledge.

Marginson, S. (2004). Global and national markets in higher education. Lecture at Keio University, Japan, 10 June, 2004. Retrieved from www.education.monash.edu.au/centres/.../revisedlecture-keio-100604.doc

Marginson, S., \& McBurnie, G. (2004). Cross-border post-secondary education in the Asia-Pacific region. Internationalisation and Trade in Higher Education: Opportunities and challenges (pp. 137-204). Paris: OECD Publishing.

Marshall, S. (2004). E-learning standards: open enablers of learning or compliance strait jackets? Presentation at ASCILITE Conference, Beyond the Comfort Zone, 5-8 December, 2004, Perth, Western Australia. Retrieved from www.ascilite.org.au/conferences/perth04/procs/marshall.html

MSN (2010, January 31). Toyota is part of a list of issues for Japan Inc. World Business on mesnbc.com. Retrieved from www.msnbc.msn.com/id/35169972/ns/businessworld_business/

Myklebust, J. P. (2009). Degree programmes miss career target. University World News, 13 September 2009, Issue: 0092. Retrieved from www.hsv.se/download/18.726d1204123dc555ee67ffe795/GREATER_ACCOUNTABILITY.pdf 
OECD (2005). Guidelines for Quality Provision in Cross-border Higher Education. Paris: OECD. Retrieved from www.oecd.org/dataoecd/33/8/34258720.pdf

OECD (2011). Testing student and university performance globally: OECD's AHELO. Paris: OECD Directorate for Education. Retrieved from www.oecd.org/document/22/0,3746,en_2649_35961291_40624662_1_1_1_1,00.html

Parker, N. K. (in press). Quality assurance and accreditation in the United States and Canada. In I. Jung \& C. Latchem (Eds.) Quality Assurance and Accreditation in Distance Education and elearning: Models, policies and research. New York \& London: Routledge.

Pirozzi, R. (n.d.). Understanding quality cost. LogiGear Corporation. Retrieved from http://www.logigear.com/newsletter/understanding_quality_cost.asp

Productivity Press (2008). What went wrong with Boeing's Dreamliner? New York: Taylor and Francis Group. Retrieved from leaninsider.productivitypress.com/2008/12/what-went-wrong-withboeings-dreamliner.html

Republic of Turkey Prime Ministry (2006). Ninth Development Plan (2007-2013). Ankara: Republic of Turkey prime Ministry. Retrieved from www2.dpt.gov.tr/konj/DPT_Tanitim/pdf/Ninth_Development_Plan.pdf

Sauvé, P. (2002). Trade, education and the GATS: What's in, what's out, what's all the fuss about? Paper presented at the OECD/US Forum on Trade in Educational Services, May 23-24, 2002. Paris: OECD Trade Directorate. Retrieved from www.oecd.org/dataoecd/50/50/2088515.pdf

Sharma (2011). Close the lecture theatres. In Higher Education, The Australian, Wednesday May 25, 2011, p 34.

UNESCO (2009). Quality Assurance in Higher Education. Paris: UNESCO/International Institute for Educational Planning. Retrieved from www.iiep.unesco.org/focus-on-higher-education/qualityassurance-in-higher-education.html

Woodhouse, D. (2006, May). The quality of transnational education: A provider view. INQAAHE Workshop. Retrieved from www.inqaahe.org/admin/files/assets/subsites/1/documenten/1259589098_quality-assuranceof-transnational-education-a-providers-view.pdf

World Bank (2007). Turkey - Higher Education Policy Study. Volume I: Strategic Directions for Higher Education in Turkey. June 2007. The World Bank: Human Development Sector Unit Europe and Central Asia Region. Retrieved from siteresources.worldbank.org/EXTECAREGTOPEDUCATION/.../Turkey_Higher_Education_Paper _062907.pdf

The author appreciates and acknowledges the advice and comments provided by Prof. Dr. Ali Ekrem Özkul, Faculty of Open Education, Anadolu University and Assoc.Prof.Dr. Yavuz Akbulut, Faculty of Education, Anadolu University, during the course of researching and writing this article. Any errors are the author's.

The author: Colin Latchem was formerly the Head of the Teaching Learning Group at Curtin University, Perth, Australia and is a past President of the Open and Distance Learning Association of Australasia (ODLAA). He now consults internationally and writes extensively on open and distance education, leadership and QA issues. His two most recent books, co-authored and co-edited with Professor Insung Jung of ICU, Tokyo are Distance and Blended Learning in Asia (201) (Routledge) and Quality Assurance and Accreditation in Distance Education and e-learning: Models, policies and research (2011) (Routledge). 